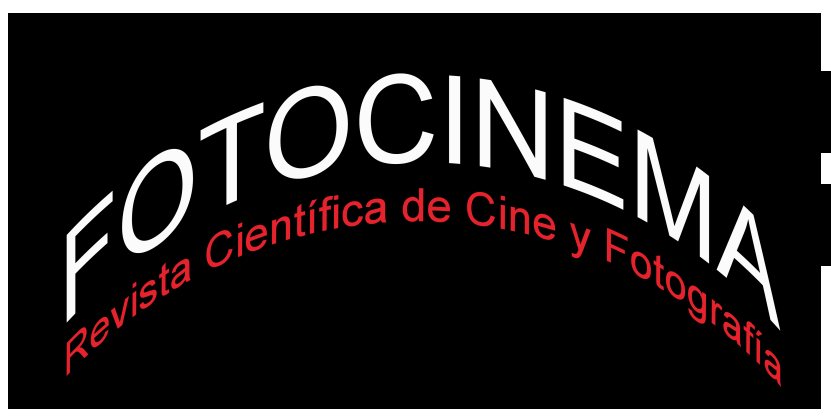

\title{
DE LA LITERATURA FANTÁSTICA AL CINE SURREALISTA CHECO: POÉTICA DE LA TRANSGRESIÓN EN KYVADLO, JÁMA A NADĔJE DE JAN ŠVANKMAJER
}

\section{FROM FANTASTIC LITERATURE TO CZECH SURREALIST CINEMA: POETRY OF TRANSGRESSION IN KYVADLO, JÁMA A NADËJE OF JAN ŠVANKMAJER}

\author{
Aimée Mendoza Sánchez \\ Universidad Autónoma Metropolitana. Unidad Iztapalapa, México \\ desideratum.ams@gmail.com
}

\section{Resumen:}

El presente trabajo expone las relaciones intermediáticas entre los relatos El pozo y el péndulo (1842) de Edgar Allan Poe y La tortura por la esperanza (1888) de Auguste Villiers de L'Isle Adam mediante su adaptación cinematográfica realizada por el cineasta checo Jan Švankmajer bajo el título Kyvadlo, jáma a naděje (1983). En principio, se detalla la forma en que ambos relatos fantásticos se relacionan en estructura y temas según las nociones narratológicas de la teoría literaria. Asimismo, se expone el procedimiento de adaptación interpretativa de Švankmajer, a partir de una lectura que aúna sendos textos para crear un nuevo argumento. De esta manera, se describen los mecanismos de transgresión presentes en la opera del artista checo, la cual se fundamenta en la incorporación y resignificación de tres aspectos esenciales como son la influencia de la poética surrealista, la tradición del teatro de marionetas de Praga y la presencia de la literatura fantástica.

\begin{abstract}
:
This article discusss the intermedial relations between the fantastic tales The Pit and the Pendulum (1842) by Edgar Allan Poe and The Torture of Hope (1888) by Auguste Villiers de L'Isle Adam in their film adaptation directed by the czech filmmaker Jan Švankmajer, called The Pendulum, the Pit and Hope (1983). Firstly, the manner in which both tales are interrelated in terms of themes and structure is explaned, according to the narrative notions of literary theory. In addition, the process of the interpretative adaptation by Švankmajer is exposed on a reading of both texts to created a new argument. In this manner, the mechanisms of transgression presents in the opera of the czech artist are describe, which is based on the incorporation and resignification of three esentials aspects such as the influence of the surrealism poetry, the tradition of the Prague puppet theater and the presence of the fantastic literature.
\end{abstract}

Palabras clave: cine checo; Švankmajer; transgresión; literatura fantástica; adaptación.

Keywords: Czech cinema; Švankmajer; Transgression; Fantastic Literature; Adaptation. 


\section{Contexto de producción y motivos de la selección}

Kyvadlo, jáma a nadèje (Jan Švankmajer, 1983) es un cortometraje de 16 minutos, en escala de grises, dirigido y escrito por el artista checo, que constituye el cuarto y último short film basado en un texto literario, dentro de su obra fílmica la cual es muestra clara tanto de sus aficiones literarias como de su capacidad para adaptar en distintos grados las diversas fuentes de las cuales se nutre su trabajo. Aun cuando sus filmes devienen de la imaginación creativa que se debate entre las metáforas visuales y las tramas reescritas debe señalarse que la complejidad expresada en sus largometrajes es fruto de la línea iniciada en sus producciones cortas, de manera que nos encontramos con un artista consciente de su arte poética, dispuesto a confrontar al espectador haciendo empleo de todas sus armas.

En este caso, se analiza un filme que se incluye dentro de una opera que rompe con la separación de las artes y conlleva optar por una visión integradora del discurso artístico debido a que la figura de Jan Švankmajer implica reconocer que las diversas disciplinas artísticas se desarrollan con igual importancia en las demás facetas de su labor creadora (artista plástico, maestro de marionetas, ilustrador, creador de objetos táctiles, escultor). De esta manera, existen tres elementos fundamentales que constituyen la filmografía del artista checo: la influencia de la poética surrealista, la tradición del cine de marionetas de Praga y la renovación literaria a partir de la reescritura e interpretación de textos del género fantástico.

Como he señalado, es indudable la influencia del grupo surrealista checo, inaugurado oficialmente por Bretón en 1935, ya que su relación con este grupo fue casi inmediata debido a la libertad artística que logró vislumbrar en dicha corriente. En una entrevista para el Festival Internacional de Cinema Fantàstic de Sitges (1994), el artista checo se pronunció a favor del surrealismo, tras décadas de haber sido publicado su manifiesto, pues desde su perspectiva:

Ya hace tiempo que el surrealismo no es sólo una 'corriente vanguardista de los años veinte y treinta, que en la historia se sitúa entre el dadaísmo y el arte 
abstracto', como lo definen los historiadores del arte, sino que es un camino espiritual (del mismo modo que la alquimia) que discurre al revés del tiempo. El surrealismo no es un arte y no tiene 'estética', por eso sería más conveniente hablar no del arte surrealista o la poesía surrealista sino del surrealismo en el arte, en la poesía, en la cinematografía. Para nosotros el proceso creativo es más importante que el resultado, que es lo que llega al mercado del arte. Por eso en nuestro grupo dedicamos tanto tiempo, por ejemplo, a la interpretación. El mundo está inundado de obras de arte a las que faltan claves. (Švankmajer, 1994, p. 5).

Respecto de la tradición checa de los teatros de marionetas, Jesús Palacios sitúa a Švankmajer en esta línea, pues recuerda que su formación profesional se originó a partir de sus estudios en el Instituto de Artes Aplicadas de 1950 a 1954 (con veinte años de edad) y en la Academia de Bellas Artes de Praga. Asimismo, menciona que Švankmajer se graduó en 1958 de la facultad de marionetas de la Academia de Arte Dramático y en el mismo año colaboró como maestro de marionetas en el film de Alfred Radok: Johannes Doktor Faust lo que le ayudó a formar parte del Teatro de Máscaras y del famoso Teatro Negro, previamente a su entrada en el teatro de marionetas Lanterna Magika, debutando como cineasta en 1964 con el short film The Last Trick. (Palacios, 2012, p. 9-22).

La influencia de la literatura fantástica en la filmografía del cineasta checo ha sido, tal vez, el aspecto menos analizado por la crítica en favor del estudio de los dos aspectos mencionados. Es notorio que la lista de títulos de sus filmes dé cuenta de la inexorable influencia literaria de sus tramas: Jabberwocky (Zvahlav aneb Saticky Slameného Huberta, 1971) y Alice (Neco z Alenky, 1988) basados en la obra de Lewis Carroll; Castle of Otranto (Otrntský zàmek, 1973-79) ligado a la obra de Horace Walpole; The Fall of the House of Usher (Zànik domu Usher, 1980) y The Pendulum, the Pit and Hope (Kyvadlo, jáma a naděje, 1983) ambos basados en la obra de Poe y Lunacy (Šílení, 2005), cuya trama no sólo retoma los argumentos de los cuentos The Premature Burial y The System of Doctor Tarr and Profesor Fether de Poe como algunos tópicos y personajes provenientes de la obra del Marqués de 
Sade anunciados desde el prefacioํ. La presencia de Poe es inexorable en la mayoría de sus filmes y de ahí deviene buena parte de aquella atmósfera irreal propia del género fantástico, la cual domina ocultamente la realidad representada por el narrador y, asimismo, ese afán de renovación estética encarnado por el autor de The Philosophy of Composition (1846), quien se erigió como un artista ligado al trabajo minucioso y disciplinado en la construcción de sus obras. La deuda respecto de la obra de Poe no es menor $\mathrm{y}$, en este caso, es importante apuntar que Kyvadlo, jáma a naděje es el último cortometraje interpretativo de Švankmajer pues a partir del estreno de su primer largometraje, Neco z Alenky, (1988), comenzará la etapa de las adaptaciones libres sin abandonar sus lecturas predilectas, como en el caso de Šílení (2005) y seguirán siendo un referente primordial incluso cuando desarrolle historias originales, o mejor dicho, inéditas, como sucede con Přežít svi̊j život (2010). Por ello, el análisis estructural del cortometraje deberá atender, simultáneamente, un análisis narratológico de los textos para poder ilustrar el grado y modalidades de adaptación en la lectura propuesta en el filme.

\section{Segmentación comparativa de las fuentes literarias}

Tanto el relato de Poe como el de Villiers se enmarcan en la tradición fantástica del cuento de manera que proponen la ruptura epistémica propia del género pues dicha renovación estilística se corresponde con el cambio de paradigma cultural a partir del siglo XIX:

[...] la poética del relato fantástico supone el registro de datos objetivos (religión, filosofía, esoterismo, magia) y su de[s]construcción, no mediante una argumentación intelectual [...] sino mediante su definición como un conjunto de sistemas de signos repentinamente no aptos para expresar y transformar, en el registro de la regulación y del orden, el acontecimiento situado en el núcleo del drama fantástico”. (Bessière, 2001, p. 87).

\footnotetext{
1. "Señoras y señores, la película que van a ver es una película de terror, con toda la decadencia propia del género [...] Puede ser entendida como un homenaje a Poe, del que he tomado diversos motivos y al Marqués de Sade al que la película debe la blasfemia y lo que tiene de subversivo" (Švankmajer, 2005).
} 
La diégesis de sendos relatos transcurre entre dos épocas distintas pero comunes al periodo de funciones de la Inquisición española - finales del siglo XV y mediados del siglo XIX: trescientos años de torturas. El relato de Villiers se relaciona directamente con el de Poe mediante un epígrafe que reproduce unas líneas del relato El pozo y el péndulo: “Oh, une voix, une voix, pour crier!” (Villiers, 1888, p.71), mostrando una fuerte relación intertextual sobre la que se construye la trama. Este relato se estructura a partir de una visión complementaria respecto de su architexto en vista de que tiene por protagonista al rabino Aser Abarbanel, judío aragonés torturado, motivo por el cual el argumento puede ubicarse a finales del siglo XV y comienzos del XVI, época de los juicios en contra de los judíos conversos en la España renacentista. En contraste, en el cuento de Poe se dice que quien se encarga de rescatar al protagonista es "el general Lasalle [debido a que] el ejército francés acababa de entrar en Toledo. La Inquisición estaba en poder de sus enemigos.” (1842, p. 47) referencia que permite ubicar el argumento durante el último periodo de funciones de la institución religiosa (principios del siglo XIX) ante la entrada de las tropas napoleónicas en el territorio español, tal como alude el narrador: "la atroz sentencia de muerte [...] que trajo a mi mente la idea de revolución” (1842, p. 38).

En cuanto al espacio diegético, los relatos se desarrollan en territorios recreados pues se mencionan los nombres de las ciudades de Zaragoza (Villiers) y Toledo (Poe). Ambos espacios fungen como sinécdoques del contexto aludido ya que, históricamente, en la primera ocurrió el asesinato del canónigo Pedro de Arbués (quien también aparece en el relato de Villiers), provocado por importantes conversos zaragozanos lo que dio como resultado el afianzamiento definitivo de la Inquisición². Toledo, por su parte, encarna otro espacio estratégico debido a que su tribunal inquisitorial mostró desde sus primeros tres autos de fe su alcance: "el día 12 de febrero de 1486 (desfilando ante el Tribunal 750 penitentes), el 2 de abril (con 900

2. Arbués fue "canónigo de la Seo de Zaragoza y primer Inquisidor del Santo Oficio en Aragón, que murió asesinado la noche del 14 de septiembre de 1485, mientras asistía a maitines en la catedral zaragozana, por unos sicarios pagados por importantes familias de judeoconversos zaragozanos, que se oponían a la implantación de la Inquisición en Aragón por orden del rey Fernando El Católico" (Museo Goya IberCaja, 2016) 
condenados) y el 11 de junio (apareciendo 750 procesados)” (Galende Díaz, 1987, p. 43). Toledo se convirtió en un territorio fuertemente defendido por las instituciones españolas frente a la invasión napoleónica, tal como indican los documentos de la época. De esta manera, los dos relatos se relacionan intrínsecamente por recrear el comienzo y el final de trescientos años de torturas y persecuciones justificadas, mediante las cuales Poe y Villiers bosquejan el horror y la desesperación interna de las víctimas, trasladándolas a su época, con el fin de confrontar al lector para suscitarle zozobra o incertidumbre respecto de su realidad cotidiana. Empero, aun cuando los textos aborden un mismo tema en dos épocas distintas, que se encuentran relacionadas, existen otros rasgos estructurales que permiten abordar la historia desde otro punto de focalización.

El pozo y el péndulo es un relato que puede dividirse en tres partes principales: la primera narra en primera persona el juicio y la condena sufrida por el protagonista debido a su filiación revolucionaria. Existe, pues, una identificación entre el narrador y el personaje principal de manera que el relato se construye a través de las descripciones aportadas por el protagonista, las cuales se basan en una percepción limitada y deformada del espacio y el tiempo ya que la penumbra en que es mantenido le impide razonar a pesar de sus esfuerzos.

La segunda parte abarca la descripción del encierro, así como las posibles hipótesis que se desprenden en la soledad del calabozo. Incluye el descubrimiento de los elementos de tortura: el pozo y el péndulo. La narración se centra en el proceso de memoria y olvido por los que pasa el protagonista ante la búsqueda de una solución a su "destino" (la muerte en manos de los enemigos). Son necesarias las analepsis para completar el proceso de recreación y para que el lector comprenda que la irrealidad se desprende de acciones simples, aparentemente mecanizadas y racionalmente deliberadas (bajo la idea del juicio legal). Existe un escepticismo ilustrado por parte del protagonista quien se niega a creer en los horrores a los que es sometido en plena Modernidad. De esta manera, el descubrimiento y encuentro con los personajes simbólicos, encarnados por el pozo y el 
péndulo, son determinantes para regir el curso de la trama ya que el protagonista comienza a ser torturado psicológicamente, primero con el pozo, al inferir el fin de aquella presencia abismal frente a la que siente un vértigo indescriptible:

Comprendí claramente el destino que me habían preparado [...] La muerte a la que acababa de escapar tenía justamente las características que yo había rechazado como fabulosas y antojadizas en los relatos que circulaban acerca de la Inquisición. Para las víctimas de su tiranía se reservaban dos especies de muerte: una llena de horrorosos sufrimientos físicos y otra acompañada de sufrimientos morales todavía más atroces. Yo estaba destinado a esta última. (Poe, 1842, p. 41)

Aunado al horror de descubrir la escenografía supersticiosa de la celda, el protagonista se da cuenta de que la oscilación percibida proviene de una hoz que cuelga del techo (relación irónica con la guillotina francesa). La narración se detiene varios párrafos para explicar la locura suscitada ante la muerte amenazante, planeada por otros que observan ocultos y se regocijan en ver la desesperación, con lo cual se logra un tiempo relativo o ambiguo, sólo aludido en voz del narrador "deficiente" quien explicita su imposibilidad para obtener información confiable en sus circunstancias.

La tercera parte incluye el plan para salir del calabozo mediante una ocurrencia extrema basada en la voracidad de las ratas (personajes secundarios) que ayudan al protagonista para salvarse del filo del péndulo. Empero, una acción desencadena otra (secuencias encadenadas) pues se activa automáticamente el segundo mecanismo de tortura: las paredes que se convierten en hogueras móviles en cuyo lienzos se representan escenas de tortura y muerte, y cuyo fin es reducir el espacio vital del protagonista a quien orillan hacia el pozo. La escena culmina con un estruendo de voces, el retroceso de las "huestes al rojo vivo" y la salvación del protagonista (al borde del pozo) por parte de general Lasalle mediante la toma de Toledo. En este caso, lo que se discute es la condena debido a una postura política y racional frente a la oscuridad representada por los jueces que juzgan y torturan al protagonista. 
El tema de la esperanza expuesto por el narrador3 da paso al título de Villiers, quien desarrolla esta idea aunque con una visión fatal en la cual la salida parece imposible, al menos históricamente. La tortura por la esperanza es un relato cuya extensión es considerablemente menor respecto del texto anterior en vista de que se centra en el intento de huida del rabino Aser Abarbanel de los sótanos de la Inquisición en la Zaragoza del siglo XVI. Ante la imposibilidad de salir del encierro, y de rememorar y escribir la experiencia, el relato se construye a partir de un narrador extradiegético que focaliza su atención en la figura del protagonista. En este caso tenemos dos personajes principales y uno simbólico: el inquisidor Pedro de Arbués, el rabino condenado y la esperanza. Existe una ambigüedad temporal debido a que no se menciona con exactitud la duración del argumento y tan sólo se indica que el encierro y las torturas recibidas por el rabino se han extendido durante varios meses, lo que conlleva la deliberación por parte de los inquisidores de acelerar su expiación mediante la muerte. La primera parte del texto presenta el espacio diegético (el calabozo), a los protagonistas y los discursos de estos (la falsa piedad, la locura institucional y el mecanismo de tortura psicológico).

La segunda parte comienza con el desplazamiento del protagonista fuera de la celda, según lo dispuesto ocultamente por el clero. En esta secuencia el protagonista experimenta un cambio anímico profundo ya que pasa de la resignación al vértigo producido por la esperanza falsamente promovida. Los personajes accidentales (familiares) y el espacio recorrido muestran el ambiente de pesadilla que circunda a dicho edificio. Tras recorrer un "viacrucis" y burlar a varios familiares, la tercera parte cierra con el desengaño producido ante la visión de lo inalcanzable, representada por el espacio exterior (montañas, bosque) y el encuentro con el inquisidor Arbués quien se muestra como una sombra que cubre a su presa, arrebatándole con ello la fe y la esperanza antes de quitarle la vida según lo dispuesto.

\footnotetext{
3. "Era la esperanza la que hacía estremecer mis nervios y contraer mi cuerpo. Era la esperanza que triunfa aún en el potro del suplicio, que susurra al oído de los condenados a muerte hasta en los calabozos de la Inquisición" (Poe, 1842, 44).
} 
Es patente que Villiers se centra en los mecanismos de coerción institucional que legitiman el discurso de la tortura, pues en ningún momento desarrolla una escena de violencia explícita, sino que se enfoca en la última hora de vida del rabí y en la tortura psicológica a la que es sometido. De esta manera, ambos relatos reproducen el verdadero horror de la violencia "oculta", psicológica, empleada por una institución para torturar a sus víctimas.

La unión de las dos tramas anteriores implica la selección de pasajes y aspectos que permitan establecer un discurso y una trama alterna que dé cuenta de la esencia de los textos y, asimismo, que sintonice con el contexto o las situaciones que el director quiere criticar o subrayar. Contrario a lo anotado por Bluestone acerca de la pertinencia de elegir un cuento corto en vista de los necesarios recortes diegéticos (citado López García, 2004, p. 704), esta cinta de Švankmajer encarna una doble operación artística e intelectual al proponer una crítica social (política, económica, religiosa, artística) y también una sofisticación técnica, en sintonía con los procedimientos escénicos que integra.

\section{Análisis narratológico de la adaptación: prólogo, epílogo y planos de enfoque}

El filme se enmarca en un prólogo y en un epílogo que corresponden al comienzo del relato de Poe y al final del de Villiers, relativamente. Durante los primeros segundos de la cinta aparecen los créditos de producción y realización de la obra, que incluye la mención del equipo de trabajo de Švankmajer, y hacen explícita de la deuda con Poe y Villiers: "na motivy povidek E. A. Poea a V. de L'Isle-Adama”. De esta manera, se pone sobre aviso al receptor acerca de la ficcionalidad de la historia (tomando distancia del cine documental) pero, sobre todo, refiriendo al estilo que regirá la nueva lectura proyectada. De hecho, la primera imagen que es mostrada al espectador es aquella en la que un hombre con capucha apaga la luz de una vela, al soplar sobre ella, en un gran primer plano (close up) que lo dota de 
misterio ya que debido a la breve distancia focal no es posible tener una imagen nítida del actor.

Asimismo, se crea cierta incertidumbre en el espectador debido a que el enfoque de la cámara no es fijo mediante el cambio repentino de tomas a partir de la ausencia de la estabilidad en la grabación. Después de la intermitencia en la cual se aprovecha el fondo negro para proyecta la parte final de los créditos, en los que aparece el nombre del director, la segunda secuencia de imagen nos deja claro que el espectador no contará con mayor información que el protagonista, en vista de que la situación es abordada mediante un plano subjetivo y el punto de focalización se centra (a excepción de algunos momentos) en la perspectiva acotada del protagonista torturado.

La cinta comienza con un travelling de seguimiento en el cual la mirada del espectador es la de un hombre escoltado por "familiares" inquisidores través de un camino incierto de pasillos. Aparecen unas manos amordazadas por otras manos como sinécdoque de la situación aludida. Al final de la intermitencia del claro oscuro natural, debido a la luz de las antorchas, se ve una puerta (entrada de la mazmorra). Literariamente, el cortometraje correspondería con el inicio formal del texto de Villiers ${ }^{4}$ y argumentalmente con el de Poe5:

La sentencia, la atroz sentencia de muerte, fue el último sonido reconocible que registraron mis oídos. Después, el murmullo de las voces de los inquisidores pareció fundirse en un soñoliento zumbido indeterminado, que trajo a mi mente la idea de revolución, tal vez porque imaginativamente lo confundía con el ronroneo de una rueda de molino. (Švankmajer, 1983).

Asimismo, el cierre del filme se logra con la aparición de otro familiar (hombre con capucha que inaugura la proyección de imágenes) quien se

\footnotetext{
4. "Bajo los sótanos de la Oficial de Zaragoza, un atardecer de antaño, el venerable Pedro Arbués de Espila, sexto prior de los Dominicos de Segovia, tercer Inquisidor General de España, seguido de un fraile verdugo y precedido de dos familiares del Santo Oficio, éstos dos últimos con antorchas, bajó hasta una mazmorra perdida (Villiers, 1888, p. 71).

5. Esas sombras de recuerdo me muestran, borrosamente, altas siluetas que me alzaron y me llevaron en silencio, descendiendo... descendiendo... siempre descendiendo... hasta que un horrible mareo me oprimió a la sola idea de lo interminable de ese descenso. (Poe, 1842, p. $39)$.
} 
proyecta hacia adelante con los brazos extendidos y avanza para encontrarse con el protagonista quien, en ese momento, se convierte en el espectador. El inquisidor llena la pantalla con el tono negro de su sayal de manera que la toma en contrapicado ascendente (pies a cabeza) sirve para exaltar su figura al mostrar su presencia como una sombra que cubre con su oscuridad expansiva al otro (min. 14:16).

\section{1. Montaje y preferencias de color}

A partir de la creación de la grabación a color la elección deliberada de filmar en escala de grises siempre es interesante desde el punto de vista semiótico, ya que aporta otro elemento de significación que contribuye a crear la atmósfera externa e interna de la trama. La vista se construye a partir de referentes sociales y, por ello, el cine se sitúa como una de las disciplinas o artes ideales para apelar a la respuesta crítica del espectador. En este cortometraje, la escala de grises no sólo sirve para evidenciar la pobreza cromática natural dentro del calabozo y los sótanos de tortura en los que se desarrollan ambas historias (espacio diegético). Es, además, un catalizador de emociones ya que en la escena de la tortura de las paredes que emiten llamas, y que contienen grabados, el espectador se encuentra ante uno de los momentos más patéticos de la trama, en el cual la celda pasa de ser un lugar sombrío a convertirse en un teatro de torturas. La escala de grises permite al espectador completar, según su criterio, el tono de los llamativos y perturbadores lienzos ${ }^{6}$. Por otra parte, es interesante mencionar que en la cinta, no existe sólo la intención de reconstruir el contexto y tiempo del argumento (siglos XVI-XIX) como de exponer una perspectiva más íntima a

\footnotetext{
6. "La entera superficie de esta celda metálica aparecía toscamente pintarrajeada con todas las horrendas y repugnantes imágenes que la sepulcral superstición de los monjes había sido capaz de concebir. Las figuras de demonios amenazantes, de esqueletos y otras imágenes todavía más terribles recubrían y desfiguraban los muros. Reparé en que las siluetas de aquellas monstruosidades estaban bien delineadas, pero que los colores parecían borrosos y vagos, como si la humedad de la atmósfera los hubiese afectado [...] las siluetas de las imágenes pintadas en los muros eran suficientemente claras, los colores parecían borrosos e indefinidos. Pero ahora esos colores habían tomado un brillo intenso y sorprendente, que crecía más y más y daba a aquellas espectrales y diabólicas imágenes un aspecto que hubiera quebrantado nervios más resistentes que los míos. Ojos demoniacos, de una salvaje y aterradora vida, me contemplaban" (Poe, 1842, pp. 42, 46).
} 
partir de la focalización subjetiva que rige a la cinta, haciendo patente el sentido agónico de la muerte casi inminente del protagonista.

Por otra parte, el montaje tiene una importancia innegable dentro de la opera de Švankmajer tal como puede ser identificado en este cortometraje. La disposición acelerada de planos, fondos y formas provoca un efecto sinestético que busca desencadenar reacciones diversas en el espectador equiparándose, de esta manera, a las configuraciones lingüísticas del género fantástico, explicadas por David Roas, las cuales:

[...] pueblan el cuento fantástico [y] participan de la verosimilitud propia de la narración realista[...] El discurso[,...] en la evocación del mundo en el que se desarrolla su historia, se hace vago e impreciso cuando se enfrenta a la descripción de los horrores que asaltan dicho mundo, y no puede hacer otra cosa que utilizar recursos que hagan lo más sugerentes posibles sus palabras (comparaciones, metáforas, neologismos), tratando de asemejar tales horrores a algo real que el lector pueda imaginar (2001, pp. 27-28).

Las secuencias en las que se decide acelerar los intervalos temporales son aquellas en que al director le interesa resaltar el contraste entre la irrealidad de los sucesos y la realidad que los contiene y genera, como sucede en los primeros cinco minutos de proyección, cuando una de las voraces ratas que salen del pozo sube al lugar en que se encuentra atado el protagonista. En el intento bestial por devorar las sobras de comida es alcanzada por el filo del péndulo, que funge como un bisturí, abriéndola por la mitad (cortando apenas la piel) y mostrando todos sus órganos internos intactos, como si se tratara de la disección por parte de un cirujano. Segundos después su cadáver es devorado por los demás roedores razón por la cual esta escena denota el espacio vertiginoso y de muerte en el que se encuentra el protagonista. Es importante mencionar que Švankmajer ha dejado claro que su particular estilo como director y animador de cine proviene, precisamente, de su iniciación como artista y no como cineasta, perfil que se puede apreciar en las animaciones incluidas en sus filmes.

\subsection{Escenografîa (mise en abyme)}


La mencionada escena del abrasamiento mediante un mecanismo "teatral" que consiste en el desplazamiento de los telones de hierro, que simulan ser las paredes del calabozo y que acorralan al protagonista precipitándolo hacia el abismo del pozo y el fuego abrasador de las llamas, es la secuencia más larga dentro de la trama (cerca de 4 minutos) y constituye la parte final de los motivos retomados del relato de Poe (los cuales dominan 11 minutos del filme). Constituye una visión teatralizada que se lleva a cabo mediante el movimiento de las figuras mecánicas ilustradas en las paredes móviles. La escena muestra a varios demonios en cuyas extremidades aparecen dos cuerpos humanos desnudos e indefensos (similares a marionetas) que son devorados, al tiempo que de los ojos y bocas de los demonios se expulsan llamas y lanzas, cuyo propósito es reproducir la tortura que representan. Pérez Bowie indica que este tipo de visiones abismales son ejemplo de la reflexividad fílmica que consiste en "la inserción de un relato audiovisual (representación teatral o filme), dentro del filme marco; el filme en segundo grado, o filme enmarcado, se presenta bajo la forma de una creación artística que "refleja" la temática o la estructura del filme que lo alberga" (2008, p. 162).

Además de la intención metanarrativa, Švankmajer hace uso de uno de sus mecanismos predilectos que consiste en el empleo de telones iletrados y autómatas poco convencionales cuya presencia manifiesta esa visión crítica de la mecanización de la sociedad en la Modernidad. Como he citado anteriormente, Jesús Palacios ha estudiado la relación entre la tradición checa del teatro de títeres y marionetas y su influencia en la obra del director checo, quien, a la par de su cine animado:

Aunque supongan una radical ruptura, en muchos aspectos, con la tradición del cine de animación checo, suponen también y al tiempo una consecuencia lógica y necesaria [...] del teatro de marionetas, ya que este, como se dijo, servía para representar no solo obras infantiles, sino todo tipo de dramas -a veces de gran carga política, como durante el Resurgimiento Nacional Checo o en la Segunda Guerra Mundial-, Además de poder expresar esferas de la 
realidad artística inasequibles a las formas realistas del teatro $-\mathrm{o}$ el cine-, representado por actores de carne y hueso (Palacios, 2013, pp. 96-97).

\subsection{Personajes}

Se ha mencionado que la focalización de la cámara es subjetiva (excepto en dos tomas en las cuales se enfoca un saco de arena que parece estar lejos del ángulo de visión del protagonista. De esta manera, los demás personajes aparecen en primeros planos, en contrapicada o comúnmente mediante planos detalles, de manera que la imagen se construye a través de sinécdoques visuales como los pies del protagonista al avanzar hacia el pozo, las manos que lo llevan apresado de las muñecas e incluso, en la secuencia de la huida, el resquicio de la puerta que le permite ver los pies de un torturado que se encuentra atrapado en otro calabozo y del cual sólo se oye un grito estremecedor.

Guillermo López García señala que uno de los fines de las adaptaciones es la reflexión "sobre la época y la tradición cultural que la ha hecho posible. Más allá de la ilustración decorativa de un texto previo a las imágenes” (2004, p. 704), lo que es aplicable también a la configuración de los personajes en esta cinta ya que los requerimientos visuales que el director busca transmitir a los espectadores son los principales elementos de identificación social en el lenguaje visual. En este cortometraje, la identificación no se logra a través de elementos convencionales como la indumentaria, la gesticulación o los diálogos de los actores, sino que se apela a la sensibilidad del espectador a través de las ausencias visuales e incluso de cualquier signo humano en los personajes que aparecen a lo largo de las secuencias, en vista de que es el sufrimiento aludido el que genera una reacción emotiva en el receptor.

Por ello, la ausencia de caracterización y el empleo de personajes simbólicos (indistintamente de si se trata de un objeto (el péndulo), un lugar (el pozo) o una sensación (la esperanza) dan como resultado un collage de metáforas creadas a partir de contrastes, movimientos parciales, desdoblamientos, la contraposición de espacios y, ante todo, de los sonidos manifestados en momentos clave de la trama. 


\subsection{Sonidos}

Un filme que prefiera la ausencia de diálogos en plena época del abuso de estos busca deliberadamente apartarse de las convenciones establecidas por el canon moderno. Ante esta elección, el director busca una ambigüedad debido a que "el título intermedio o el escrito manifiesta la ley..." (Deleuze, 2004, 297-298). En Kyvadlo, jáma a naděje, se pone de relieve que el protagonista se ve reducido a un trato animal o incluso inanimado ya que su movilidad, al inicio y al fin del corto, es guiada y permitida sólo por los inquisidores. Incluso la falta de voz en off y los pocos sonidos humanos denotan precisamente la ausencia de humanidad en la institución religiosa. De hecho, la única vez que predomina un sonido humano es cuando el protagonista jadea mientras se esconde entre los pasillos y cuando el segundo prisionero grita de dolor ante la tortura (mismo grito que inaugura el cortometraje).

En contraposición, el canto de las aves, que se introduce con el descubrimiento de la grieta que da paso al exterior, es una melodía natural que simboliza el único rasgo de libertad del cual carece el protagonista. Asimismo, se muestra contrario a la voracidad de las ratas, que si bien ayudan al protagonista para salvarse del filo del péndulo, éstas están en constante relación con la muerte (salen de pozo, devoran), y los sonidos del fuego, las cuchillas, la guillotina, y demás artificios de tortura que sólo crean la atmósfera de sufrimiento.

Frente a una cinta carente de diálogos e incluso de gesticulaciones y de color es importante cuestionarse de qué manera se construye un sentido unívoco, en el caso de que lo haya, del relato visual. Švankmajer logra, en algunos de sus filmes, construir discursos y críticas prescindiendo de los diálogos y muchas veces de actores en beneficio del empleo de objetos y texturas disímiles o de marionetas e ilustraciones que pueden considerarse verdaderas metáforas tangibles dentro de sus cintas. En el caso de Kyvadlo, jáma a naděje, la ausencia de diálogo transmite tanto la incapacidad de comunicación como el horror de lo inefable e indescriptible. La ausencia de 
identificación corporal denota que la víctima no es específica (como un revolucionario en el caso del relato de Poe o un rabino en el caso de Villiers), sino que cualquier ser es susceptible de ser objeto de violencia sin importar la época, pensamiento, estatus social, etc.

\section{Valoración global}

Como menciona Pere Gimferrer, el surrealismo no es simplemente una doctrina de manifiesto sino "una realidad litúrgica, sensorial, de representaciones y apariencias desplazándose, tiene más que ver con el mundo mental que con el visible, más con la realidad interna que con la externa. Como una estatua de dos rostros, el cine nos enfrente a la realidad y nos sustrae a ella” (1999, p. 149). En este sentido, la atmósfera onírica del surrealismo puede convertirse en un medio para evocar no sólo el inconsciente creativo como también lo reprimido, el trauma. Si tomamos en cuenta que el fin del arte, en cualquiera de sus manifestaciones, es la apelación al otro (el cual puede ser un desdoblamiento del autor, un espectador, una instancia ideal o una física) mediante el pathos o la razón para lograr una libertad consciente, es claro que, en el ambiente de represión política checa durante el siglo pasado, un discurso artístico, por más abstracto que parezca, no puede desligarse de su contexto.

El filme analizado se rodó después de los ochos años durante los cuales le fue prohibido a Jan Švankmajer hacer cine, durante la década de los 70, debido a las restricciones del gobierno checo en torno a las manifestaciones artísticas que se consideraban transgresoras del realismo. La difusión de sus filmes fue limitada - actualmente existe una situación similar que responde a otros móviles más afines con la postura hedónica del autor respecto de su obraempero, su visión crítica respecto de las estructuras e instituciones sociales se fueron arraigando en sus cintas. Esa lucha constante por denunciar la violencia social a la que somos sometidos no sólo se refleja en aspectos técnicos como la búsqueda de financiamiento económico en países "democráticos", como sucedió en el caso de The Death of the Stalinism in 
Bohemia (Konec stalinismu v Cechàch, 1990) financiada por un productor del Reino Unido, sino que también se refleja en la predilección por adaptar textos literarios que encarnen, de entre otros tópicos, la dicotomía entre la locura creativa y la locura institucional como una forma de violencia. En entrevista con Juana Ruiz, para la filmoteca española, el director checo aseveró que "en el fondo todas mis películas hablan de la libertad contra la manipulación. La libertad es, en mi opinión, el único tema por el que aún vale la pena coger un pincel, o una cámara o intentar crear" (Švankmajer, 2012, p. 64).

En correspondencia, debe anotarse que la censura a la que fue sometido el cortometraje analizado volvió explícito el mensaje aludido en la trama ya que "[In the case of The Pendulum, The Pit and Hope (1983),] Oficial censors were able to deactivate the self-evidence reference to the present -the time of a 'normalized' CSSR in a neo-Stalinist fashion- by adding end credits that named the number of victims of the Holy Inquisition, thereby clearly historicizing the subject. The director's protest was in vain" (Schlegel, 2013, p. 47). De esta manera, debe reconocerse el acierto del director en lograr transmitir un mensaje crítico concerniente no sólo respecto al contexto político de su país, sino que logró romper con los condicionantes políticos para exponer que en cualquier sociedad existe un mecanismo de violencia rigente, llámese Inquisición, estado democrático, comunista, socialista, Banco mundial, etc. Aunque la postura del artista checo acerca de su obra puede considerarse ambigua es cierto que una de sus principales puntos de atención es el público (no en un sentido meramente comercial), pues sigue apelando a una recepción activa. Como analiza Javier Ludeña Fernández:

[...] en Kyvadlo, jáma a nadeje, 1983, al estar contado con cámara subjetiva, el prisionero del relato de Edgar Allan Poe es el propio espectador, y sus captores, a falta de más información, pueden ser cualquier sistema opresor, impresión acentuada por las escenas católicas de dominación que se ven en las paredes móviles de su celda. Y así sucesivamente (2010, p. 1).

Consecuencia de lo anterior es que en el cortometraje el sustrato literario se nutre mediante una adaptación interpretativa que utiliza elementos fílmicos 
para recrear la atmósfera y el estilo de los autores literarios, quienes suelen tener una fuerte presencia e influencia en el autor como sucede en el caso de Poe. No debe olvidarse que las historias literarias, de la extensión que sean, nunca son unívocas, pues en eso reside su valor artístico: en sugerir más allá del argumento que tratan, renovándose a través del tiempo, valor que comparten con todas las demás formas verdaderas de expresión artística.

\section{Referencias bibliográficas}

AA. VV. (1994). El llenguatge de l'analogia (El lenguaje de la analogía). Sitges: Festival Internacional de Cinema Fantástic de Sitges, trad. De Monika Zgustová.

AA.VV. (2016). Martirio de San Pedro de Arbués. En Museo Goya IberCaja, disponible en http://museogoya.ibercaja.es/obras/martirio-de-sanpedro-de-arbues\#

Allan Poe, E. (2009) [1842]. El pozo y el péndulo. En Carlos Fuentes y Mario Vargas Llosa (Pref.), Fernando Iwasaki y Jorge Volpi (Eds.). Cuentos completos (pp. 38-47). Madrid: Páginas de Espuma, Trad. De Julio Cortázar.

Schlegel, H.-J. (2013). Religion and Politics in Soviet and Eastern European Cinema: A Historical Survey. En Liliya Berezhnaya y Christian Schmitt (Eds.), Iconic Turns: Nation and Religion in a Easter European Cinema since 1989 (pp. 33-64). Leiden: Koninklijke Brill NV.

Bessière, I. (2001). El relato fantástico: forma mixta de caso y adivinanza. En David Roas (introd., comp., y bibliografía), Teorías de lo fantástico (pp. 83-106). Madrid: Arco Libros..

Deleuze, G. (2004). La imagen-tempo: estudios sobre el cine. Madrid: Paidós, trad. de Irene Agoff.

Galende Díaz, J. C. (1987). La Inquisición borbónica toledana: su intervención en las causas de bigamia. Cuadernos de estudios manchegos (17), 43-67.

Grimferrer, P. (1999). Cine y literatura. Barcelona: Seix Barral.

López García, G. (2004). ¿Un amor imposible? Las complejas relaciones entre literatura y cine. En Miguel Ángel Muro Munilla (coord.), Arte y nuevas tecnologías: $X$ Congreso de la Asociación Española de Semiótica (pp. 700-711).

Ludeña Fernández, J. (2010). Jan Švankmajer: stop motion y surrealismo. Revista Fantastique literatur.blogspot.mx/2010_02_01_archive.html.

http://cine-y-

Palacios, J. (2012). Iluminaciones. El cine de Jan Švankmajer. En Eugenio Castro y Julián Lacalle (Eds.), Para ver, cierra los ojos, (pp. 9-44). Logroño: Pepitas de Calabaza. 
Palacios, J. (2013). La linterna mágica de Jan Švankmajer. Animación al rescate (3), 92-107.

Pérez Bowie, J. A. (2008). Leer el cine: la teoría literaria cinematográfica. Salamanca: Ediciones Universidad de Salamanca.

Roas, D., (2001). Teorías de lo fantástico. Madrid: Arco Libros.

Ruiz, J. (2012). La poesía imaginaria. Caiman cuadernos de cine (2), p. 64.

Švankmajer, J. (1983). Kyvadlo, jáma a naděje. República Checa. Krátký film Praha.

Švankmajer, J. (2005). Š́lení. República Checa. ATHANOR: společnost pro filmovou tvorbu.

Villiers de L'Isle Adam, A. (2012) [1888]. La tortura por la esperanza. Nuevos Cuentos Crueles (pp.71-73). Barcelona: Espasa.

Cómo citar: Mendoza Sánchez, A. (2016). De la literatura fantástica al cine surrealista checo: poética de la transgresión en Kyvadlo, jáma a nadèje de Jan Švankmajer. Fotocinema. Revista científica de cine y fotografía, $\mathrm{n}^{0}{ }_{14}$ pp. 275-293. Disponible: http://www.revistafotocinema.com/ 